\title{
Nurturing High Expectations: Living a Well-Lived Curriculum on a Humanistic Perspective
}

\author{
Markus Budiraharjo, M.Ed., Ed.D.
}

Sanata Dharma University

\begin{abstract}
This study reports an empirical investigation of the use of personal approach to integrating educational values in an English pre-service teacher education program. Using a Moodle-based Learning Management System called Exelsa, which has beeen in use in the past four years, each individual student received personal written responses from the instructor. Learning is perceived more as a journey to develop self-knowledge that is not merely driven by instrumental orientations such as grade-seeking mentality, rote memorization, and formalist-driven contents. A set of anedoctal evidence suggested that highly personal notes addressed to each individual student brough significant change in the way each of them viewed himself or herself in positive ways. When students felt highly appreciated as significant human beings in the class, they were more likely to undergo learning more in a holistic manner. A humanistic philosophy of education necessitates such an approach to maintaining a relational trust among all class members. An instructor is supposedly skillful at navigating the flows of class interactions, at times with unprecedented challenges. $A$ restropective study, this seeks to develop a better understanding as to whether such an approach leaves a durable significance in their perspectives on learning.
\end{abstract}

Keywords: humanistic curriculum, high expectation, pre-service training.

\section{A. INTRODUCTION}

This paper sets out to explore how a humanistic curriculum is enacted in the English Language Education Program (ELESP) of Sanata Dharma University, Yogyakarta. Its discussion is centered on the implementation of curriculum in a course named Critical Reading and Writing I offered for the third semester students (odd semester, academic year of 2013/2014). Considered from its epistemological standpoint, most discussions done on the curriculum are a representation of Tylerian Rationale. Kliebard's (2004) historiographic accounts on the emergence of curriculum as a disciplinary inquiry presents the huge wave upon which Ralph Tyler's (1949) proposal for curriculum development strategies had taken hold. Tyler's legacy in setting up a long standing curriculum design model has been largely viewed from its simplicity and functionality. The rationale delineates four major steps, including the identification of instructional goals, necessary materials to cover, important strategies to use, and approprate evaluation steps to take.

In the ensuing years, the curriculum inquiry has witnessed a range of curriculum design models, such as Hilda Taba and Oliva in the 1960s, and Dick and Carey (1996), among others. All of them are categorized into one particular group of curricular model developers. Up to this day, Tylerian legacy remains strong with the reemergence of backward design (Ozar, 1994), and McTighe \& Wiggins (2005). Tylerian rationale has been highly influential in the development of curricula in Indonesia. The main agenda of such a rationale is its systemic orientation, where teaching and learning activities are 
viewed as delivery systems that involve both behavioral and cognitive psychologizing (Taubman, 2007). From a bureaucratic sense, a systemic model for curriculum developments is seen to offer a relevant strategy to engage many schools and teachers. In this model, curriculum development processes are cut into some procedural steps, where particular, standardized operating procedures are to develop. There have been seven formal curricula stipulated in Indonesia since 1968, and all have drawn much from such a systemic model.

The current discussion on the curriculum offered in this paper sets out a different outlook on the nature of curriculum. The curriculum is seen from a sociocultural perspective, where a humanistic orientation gains more weight. It is my conviction that today's discourse community in curriculum theorizing has been co-opted by a singularity of views, especially the one endorsed by the government. The influence of highly prescriptive model of curriculum developments has been all-encompassing. Two guiding questions proposed in this study are as follows: (a) How did classroom built around humanistic curriculum look like? (b) How did students perceive their learning established on humanistic curriculum after the semester past?

\section{B. REVIEW OF LITERATURE}

In contrast with general views on systemic perspectives of curriculum, this study draws much discussion on a sociocultural perspective (Budiraharjo, 2014). In the contemporary discourse of curriculum, a linear, systemic view of curriculum has largely made schools and teachers left impoverished (Hansen, 1998; Sprinthall, Raimes \& Thies-Sprinthall, 1996; Pinar, Reynolds, Slattery, \& Taubman, 1995). Considered from such an instrumentalist rationality, most people are forced to talk about curriculum in response to the formal policies issued by the government. The allencompassing discussions are very likely to refer to the power of polity, and therefore all seem to get trapped within a socio-regulative sphere. A socio-cultural perspective allows us to comprehend the enacted and lived curriculum from a starkly different angle.

Accordingly, curriculum is thus viewed as a representation of the complexity of geological layers of lived experiences undergoneby some school communities for an extended period of time (Darling-Hammond, 1997). Within this highly contested field of curriculum as lived experience, lies a variety of ideological underpinnings. Kliebard's (2004) historiography on the emergence of curriculum as an independent discipline of inquiry underscores four ideological assumptions that had contributed to its establishment. The four areas include traditional intellectualist, efficiency, child developmentalist, and reconstructionist. In short, out of the four contesting assumptions, it is the efficiency model that eventually wins the battles. Upon the delineation of Ralph Tyler's (1949) rationale for curriculum development, the curriculum development programs holds to be highly systemic by nature. Given the increasing trends of audit culture in such neoliberalistic ages and standards-based movement, curriculum development remains to be largely document-based (Taubman, 2007). The very trend strongly appears in the most recent curriculum, i.e. Kurikulum 2013 (dubbed as $\mathrm{K}-13$ ), formally enacted by the Yudhoyono administration, where teachers are seen merely as technicians.

Raising the curriculum within the area of lived experience promises a far greater depth of investigation. First, the existing practices in schools are a representation of culture or habits of mind shared by the school community. The empirical data obtained from the study by Budiraharjo, Muljani, Baskara, Nurmandi, Mutiarin, \& 
Qodir (2014) underscores such patterns. The implementation of the 2006 School-Based Curriculum (Kurikulum Tingkat Satuan Pendidikan) has not necessarily brought significant changes in teaching practices. The curriculum has shown to have influenced more on the open governmentality by the schools. The inclusion of school committee members in the school governance allows better community participation in school management. The findings of the study corroborate Bjork's (2013) empirical findings with regards to the power of traditional teaching practices among Indonesian teachers. New jargons about constructivism, collaborative learning, and student-centered learning are generally adopted as fads, but not necessarily change the way teaching activities are conducted. Bjork (2013) notes that pedagogical methods being used by ordinary Indonesian teachers generally consist of 53 per cent of all lessons being used for lecturing, 20 per cent for working on worksheets or hands-on activities, and the last 5 per cent for a class discussion.

Second, raising the issues of curricula as lived experiences by each school will offer a more colorful portrayal of reality. In the study on 92 Catholic and Muhammadiyah elementary and junior high schools in Yogyakarta Special Province and Central Java, Budiraharjo, et al. (2014) found that each religion-based school has particular ways of doing things. Many good practices that we can draw from how school community manages their lives in the school are highly encouraging. It is therefore imperative to bring forward some discussions on the curriculum as lived experiences that are demonstrated by the schools.

The main agenda to raise the discussion of curriculum beyond the instrumental rationality draws a lot from a philosopical perspective, which defines humanity and ways to keep the humanity to thrive through educational enterprises. Education is not only intended to teach students with technical and cognitive knowledge and skills, but it provides a room for them to engage with their humanity. From its etymological standpoint, the presence of teacher to facilitate teaching and learning was more motivated by the moral responsibility in the form of services, i.e. helping the young generation to grow (Dawson, 2005). As Drijarkara posits, education itself is seen as a fundamental act. An expression of anger can be highly educational given some appropriate considerations such as contexts and intentions. It can also be highly uneducational when it intended to take revenge or belittle others. Palmer (1998) also underscores the importance of meaning making process found in teaching activities. Teaching and learning activities in the class are a phenomenon that cannot be reduced to some methods or techniques. He recalled one of his most everlasting teachers in his life as the one being so strict and combative.

In their sociological study of small Catholic schools throughout the country, Bryk, Lee \& Holland (1993) found that the humanity is found to thrive well in small school contexts. Drawing on Vatican Council II teachings on subsidiarity, small school contexts allow people to know each other. It is believed that humanity has a room to flourish when each person is seen as a unique entity, filled with all potentials and drawbacks. Multicultural perspectives of teaching have been drawn from such a humanistic view that puts each human being meaningful by oneself. Each is called by his or her own name. Each person is known well as the one having particular life history that is so uniquely crafted in one's life tapestry.

Humanistic perspectives on curriculum will bring the basic principles of high expectations into operation. As vastly practiced by Marva Collins in one of the 
private schools to serve the poorest groups of students of color, the major orientations of humanistic curriculum are targeted to engage teachers with each student's individual problems. The basic attutide nurtured among teachers is the assumptions that each student, no matter what their backgrounds are or what color of skin he or she has, the student deserves unique attention.

At this point, a humanistic perspective leads to transformative learning on the part of the instructor (Mezirow 1978, 1991, 2000). My own research on the professional development among 10 Indonesian teachers attending a US higher education underscores a basic characteristic of transformed self (Budiraharjo, 2013). Well-transformed persons are those who set out to define an ontologically subjective realm as the utmost significance, where the process of critical self-reflection on assumptions is oriented to self in relation to other people and things (Brookfield 2000, 2009). It means that the reflective practices are intended to attend own circle of influences. On the other hand, non-transformed self is indicated with the external objects of reflections. The realm of personal inquiry for non-transformed self is objective reframing, i.e. maintaining critical stance over what others have done, and excluding self. The sense of agency among those non-transformed is diminished because they perceive reality as externally formidable constraints. Within this frame of mind, my inquiry in the humanistic curriculum as lived experience is thus gounded on delineating my own biographical component as the instructor of the class (Cooper \& White, 2005).

In sum, efforts to discuss a humanistic curriculum place the class instructor as both major inquirer and major human research instrument in the core business of investigative enterprise. Self-transformation is viewed as a worthwile goal so as to allow humanistic values, such as maintaining high expectation attitude, being a highly authentic listener, and being ready to change and to be changed by dynamically complex encounters of human relations.

\section{METHODOLOGY}

This study drew heavily from qualitative traditions, where personal narrative and phenomenological investigations with regards to the area of inquiry are of great importance (van Manen, 1990; Sokolowski, 2000; Moustakas, 1994; Moran, 2000). Qualitative research relied on a variety of the data sources drawn from interactions, observations, and conversations. Interviews and focus group discussion were used to gather the data. The interviews were jotted down, and ideas drawn from focus group discussion were noted and embedded in personal reflective logs. The data were also drawn from archival documents posted in the University's learning management system called Exelsa. The participants were all students involved in the class. Drawing on phenomenological inquiries, the researcher intended to capture the phenomenon of learning by admitting personal imposition of meanings and values and remaining highly critical by bracketing self and conceptual thoughts. Participatory knowledge construction took place by engaging research participants to access the knowledge under construction.

\section{FINDINGS AND DISCUSSION}

This study sets to address two major problems, i.e. (a) How did classroom built around humanistic curriculum look like? (b) How did students perceive their learning established on humanistic curriculum after the semester past? In order to answer the first problem, three major characteristics of the curriculum implementation are described. First, a humanistic curriculum necessitates 
the accomplishment of a systemic curriculum model. It does not stand by itself. The nutsand-bolts of curriculum development draws much from systemic model. Second, a humanistic curriculum requires a high degree of flexibility in response to dynamic challenges. Third, a humanistic curriculum meets its full expression when axiological considerations are made in response to reality. The second question will be addressed through an analytical tool of personal narratives of curriculum enactment.

\section{Systemic curriculum development as a prerequisite}

It is worth noting that the implementation of a humanistic curriculum never eliminates the responsibility of teachers or instructors to develop curriculum, syllabus, and other instructional preparations. The nuts-and-bolts of curriculum development heavily lies in the systemic model. In particular, I made use of McTighe \& Wiggins' (2006) basic principles of backward design. In developing the courses, the standards operating procedures were drawn from a backward design model (Ozar, 1994; McTighe \& Wiggins, 2006) with three simple steps, i.e. defining goals, developing learning assessment, and developing strategies. Based on my professional experience conducting a series of instructional leadership programs to school principals in Yogyakarta, Jakarta, and Surabaya in the past three years, the three-step-activity in course development is of great value. In my case, the course Critical Reading and Writing I was seen as one of the skills-based courses. Its goals are set to induce criticality or reasoning abilities through reading and writing activities. Given that the course is offered to the third semester students, academic orientations, their self-identity, and future employments are at a nascent stage. Related to academic skills, many still struggle with grammar, pronunciation, and general literacy abilities. Some demonstrate a high degree of metacognitive skills, such as being skillful at monitoring their own thinking and finding ways to compensate their weaknesses. Most of them, however, seem to have problems with their academic skills in general. Based on the data gathered by the study program, the majority of the students comes to attend the English Education Department only with some motivation to acquire English, not to be English teachers. The majority third-semester students is also very unlikely to have stable views on who they are and what they want to be. It is the conventional wisdom shared in the study program that the first four semesters serve as a foundational experience because many students are still standing in shaky grounds. The majority students comes from neighboring towns, such as Klaten, Bantul, Sleman, and Kulon Progo. Only small fraction of students comes from other islands. In sum, all components of curriculum development, such as gathering information about who students are, where they are from, general academic skills, their English proficiency levels, and the position of the particular course under investigation, are appropriately addressed.

\section{Highly flexible enterprise}

I have learned a lot from my experience in blindly following a prescriptive set of procedures of teaching reading and writing skills. While a systemic approach to curriculum development provides some stability, in the same time it also leads to inflexibility. A humanistic view of curriculum development alleviates the burden of blind obedience to such rule-governed, highly prescribed sets of activities. In the English Department, a highly procedural strategy in teaching seems to apply well in some courses which are algorithmic by nature. The instruction in pronunciation class is likely 
to be included in this algorithmic model, because the intended goal of such a class is the acquisition of pronuncation skills related to predetermined set of some sounds. When the activities of the class tend to be oriented to some isolated skill, such as maintaining accuracy in pronouncation and grammar, the tasks are highly structured. A critical reading and writing class presents a further challenge when it is understood in this realm. There are too many issues taking into account. We have vast arrays of reading resources available at our fingertips. We also know that writing skills are of highly unstructured. In reality, the pragmatic uses of English require the speakers to process a variety of information, many of them are too subtle to recognize. Skillful language users are very likely to be unaware of the complexity involved in the production of a correct piece of statement. It is therefore much safer to put the critical reading and writing class more as a heuristic, rather than algorithmic. In a heuristic model, teachers are expected to address the students personally (by their own names), engage them with meaning making constructions, and provide necessary feedbacks to them. The flexibility is thus of paramount importance in developing humanistic curriculum.

\section{Axiologically oriented}

When the high flexibility of curriculum implementation is in place, an instructor needs to draw much from the values, assumptions, and beliefs held by the institution. Our recent research among Catholic and Muhammadiyah schools in Yogyakarta and Central Java highlights the power of school culture and axiological orientations based on their ideological beliefs (Budiraharjo, Muljani, Baskara, Nurmandi, Mutiarin, \& Qodir, 2014). An axiological orientation refers to the values held strongly by the institution. It is found that religionbased schools have been highly contributive in teaching the young the values. The empirical data from the field demonstrate that these schools are not merely driven by instrumental rationality, but some values such as service, sacrifice, inclusion, empathy, compassion, and high expectations are raised.

Sanata Dharma University is one of the private universities. It is affiliated to Catholicism, and more particularly it is owned by the Jesuits. Since its early inception in 1955, Rev. Drijarkara, SJ, a renowned philosopher and founder of the institution, set out to induce Catholic identity with a commitment to serving the community at large by preparing young generation of teachers. Education is seen to be a fundamental act, where the meaning is drawn from its contexts and consideration. An expression of anger is seen to be wrong when it is done for the purpose of venting uncontrolled emotions off. However, it is an educational act when it is done in the right contexts and appropriate considerations.

Drawing upon his own experience, Palmer (1998) suggests that teaching can never be reducible only into some labels, such as student-centered approach, projectbased learning, constructivism, etc. Upon his years of teaching experience, what resides most in his memory about his teachers is the one that had changed him a lot. The teacher who had changed the course of Palmer's personal life was not a "good teacher" in an ordinary sense. This teacher kept lecturing all the time. After years being detached from such an experience, Palmer eventually made a striking conclusion. The real teaching happens when there is a unique encounter between a teacher and a student, where they can communicate the meanings of life, and how the encounter remains to live as a guide. Such an encounter will only take place in a genuine context, where a person feels needed and personally acknowledged. Teaching carries moral values (Hansen, 2008), and 
therefore it always deals with selecting the most appropriate things for students.

I place myself in the class being a teacher who seeks to address each person. It is not an easy enterprise. However, given the fact that humanistic perspectives are in the air of the whole university, I do not feel isolated with this unique perspective. From my encounters with other colleagues in the study program, I learned that the very class that I was teaching was problematic. The academic gaps were very wide. Three students were top performers. Most students had good grade point average (above 3.1 out of 4.0 scale). However, the real performance of the majority of the students was poor, i.e. below 3.0. This was a striking finding. From the academic advisor of the batch, I learned that the atmosphere of the class turned more and more toxic. Unhealthy relationships of some class members led to a hostile ground for the whole class. Based on the data gathered from their essays, reflections, and personal interviews, I quickly learned that it was the class atmosphere that made them unhappy. Some felt so devastated with the hostile atmosphere of the class.

Seeing this challenge, I came to conclude that some personal approach might work. To obtain a ground that was relevant to them, I developed a shock therapy using Palinscar \& Brown's reciprocal teaching strategy. I assigned each student to generate questions in a timed test. The individual oral test was new to them. They were not familiar with the method, and I made myself very strict. It followed that the atmosphere was so tense. I told them that the results of the oral test would determine their grade. This was a shocking experience to them. In the evening, I received an email from an acquintance, a school superintendent in Yogyakarta. She was curious why her daughter came to her in tears. She learned that my class of that day was too shocking to her daughter. She asked me the rationale why the class was so hurtful to her. This email was certainly an unprecedented one to me. I did not know that my acquintance's daughter was in my class.

I replied her email, explaining the toxic nature of the class. I had a strong reason to be strict at that time, because I planned to make all the students aware of their being selfish. Further emails between us helped her know exactly my goals. She endorsed my shock therapy to the class. To make it short, after that day, I changed my ways of responding to the class. I gave more rooms for improvements and revisions on their drafts. In addition, many class discussions afterwards were also geared to bring the importance of high expectations. A case in point, I brought a draft written by a student from the Mollucas. She wrote about her struggles to come and study in Yogyakarta. The draft had some grammatical mistakes. But, my focus was not to embarass her. I praised the power of imagination and willingness to suffer a lot on the part of her, especially since she presented her authentic self through her draft. I appreciated her being so outspoken in her draft, allowing me to know her in person. In this way, I taught the class the values of appreciations, which seemed to evade due to internal conflicts. I brought a sense of community in the class.

In sum, that is exactly the humanistic curriculum that I have implemented. I maintain a good amount of personal appreciation to each person, and in the same time teach them not to feel sorry to own weaknesses.

\section{Personal narrative of curriculum enactment}

One important thing to raise is that throughout the semester the students learned a lot to engage in their learning. By the end of the semester, some students reported to have a better view about the 
community of learners. They could assess the different quality of relationship by the end of the semester. It was through humane encounters in the class created altogether that they learned to be at ease even when tensions took place. It was my expectation that the change in their perspective was durable, in the sense that they remained to maintain the belief and made use of it to respond to new challenges in new classes in the next semesters. Unfortunately, it was not the case. About two months after the new semester was underway, many students complained about a particular teacher.

My quick response to reflect on the complaints that I heard was that the change in attitude or perspective drawn among them were short-lived and temporary. They reported to have suffered from different ways of this particular lecturer in feedback provision. These students found that the written feedbacks on their writing drafts were too mechanistic. The written comments were similar among students. The students found themselves "unrecognized" by the lecturer. They did not feel appreciated. Some students compared the ways I provided personalized feedback, which was unique to each person. I found personal touches important to build personal rapport among my students. The Moodle-based learning management system called Exelsa was of great importance for me, because I could write my responses as much as I want. These students found personal "letters" in the form of personalized feedback a powerful way to motivate them to learn. They missed such a kind of personal relationship.

Second, these students also demonstrated frustrations with the lecturer due to his being highly insensitive in feedback provisions. They did not deny that the lecturer was highly intelligent. According to the students, being intelligent was different from being compassionate and emphatic.
Some of the class members were devastated with unprecedented feedback provisions. In response to this complaint, I jokingly argued that I had done the same. I did give them real feedbacks, such as some grammatical points to revise. I also shared the grammatical mistakes that they made in public. Anne, one of the students responded: "they way you put the feedbacks was different, Sir. [It was true] that you gave feedbacks. You did it indirectly. You invited us to have discussions first, and then the grammatical feedback came later."

It is my belief that feedback provisions are not merely related to technicalities. In a humanistic perspective, human relations remain to be strongly influential in the educational enterprise. It is a healthy relationship, where each participant shares the same ground and concerns, that leads to productive and constructive atmosphere (Bryk \& Schneider, 2003). The ways of feedback provisions shown by a colleague of mine are very likely to be seen as drawing from a deficit model. It is not drawn much from a high expectation perspective. Anne was clear in identifying the ethical breach in the feedback provision. She and her friends underwent some devastating moments when the lecturer looked down on them.

Drawing on a high expectation perspective, I mostly develop to grow a shared awareness that everybody is unique. It is through personal responses to their drafts and personal essays that I am able to build personal rapports to each student. Thanks to web-based learning management system being used in the University, I can extensively write personal feedbacks to each person. I usually highlight the importance of their existence in the class. It follows that each student becomes a meaningful entity in the class. A personalized comment on each draft (especially in the first two months) allows me to develop a good relationship on each student. 
Building a good relationship is not an end in itself. It is just a means to know each other. The next step is to raise the importance of knowing self with regards to the skills to develop. At this point, I place myself as the one appreciating the mistakes that occur among students. Instead of blaming them for their being inaccurate, I tell them that we need to have a good reason to be happy, especially when we know that we are not perfect human beings. Everybody makes mistakes and errors. Grammatical errors and mistakes as well as inacuracies in pronunciation that we make do not make ourselves bad or even evil. We learn through mistakes and errors. The question is whether we are ready to embrace the attitude of being highly critical to ourselves or not. Good people are very good at learning from a variety of fronts. So, I invite them to learn from each other, and self, and from the meaningful and constructive relations in the class.

I fully realize that the way I motivate the class allow me to empathize to imperfection among humans. However, in the same time, I also invite them to gear towards personal accountability. This is the way I conduct a curriculum oriented to humanistic values. I do not stop critizing my colleagues due to their failure to make the humanistic values meaningfully implemented in their classes. I keep myself being critical to myself. Writing this research report is far from being an agenda to self-valorize. I can see the drawbacks on this humanistic perspective. An overemphasis of a humanistic perspective is likely to lead to a spoiled attitude, which can even threat students' autonomy. From the empirical data that I raise in this paper, many students were not happy when the new lecturer did not continue my approach. I could speculatively argue that my previous approach even create a high degree of dependency among students. When they encountered harsher atmosphere they complained a lot.

\section{E. CONCLUSION AND RECOMMENDATION}

Two major conclusions can be drawn from this paper. First, the core business of education is in fact how to build highly meaningful relationships both in and out of the classrooms. The curriculum established around humanistic values are highly personal and mostly dependent on the particular characters of the instructor and the students. Second, despite the long standing commitment to bringing humanistic values in the lives of the whole university community, it is clear that a full adoption of this core value is never final. The university has placed the emphasis on humanistic curriculum since its inception in 1955, when the goal of establishing a higher education institution was to prepare young generations to be teachers. The empirical data presented in this paper yields that the struggles to make this commitment down-to-earth remain a daunting task.

It is therefore imperative for the university to embark on another path to go. To satisfy an academic inquiry, I would assume that further studies, especially conducted through an interpretive inquiry, will allow the discourse community to grow and develop a greater depth of understandings on the nature of self and community. It is clear that I do disservice to a colleague of mine (discussed in this paper) if I do not involve him in search of better professional paths. Data gathering methodologies, combined with on-going data analysis processes, that allow both professional and personal transformative learning to grow, are supposedly to be exercized.

\section{REFERENCES}

Bjork, C. (2013). Teacher training, school norms and teacher effectiveness in Indonesia. In Daniel Suryadarma \& Gavin W. Jones (Eds.), Education in Indonesia (pp. 53-67). Singapore: Institute of South Asian Studies. 
Brookfield, S.D. (2000).Transformative as ideology critique. In J. Mezirow, \& Associates (Eds.), Learning as transformation (pp. 125-148). San Francisco: Jossey-Bass.

Brookfield, S.D. (2009). The concept of critically reflective practice. In A.L. Wilson, \& E.R.Hayes (Eds.), Handbook of adult and continuing education (pp. 33-49). San Francisco: Jossey-Bass.

Bryk, A.S., Lee, V. E., \& Holland, P.B. (1993). Catholic schools and the common good. Cambridge, MA: Harvard University Press.

Budiraharjo, M. (2013). A phenological study of Indonesian cohort group's transformative learning. Dissertations, Paper 507, accessible at http://ecommons.luc.edu/luc_ diss $/ 507$

Budiraharjo, M. (2014). Kurikulum sebagai kontestasi nilai dan implikasinya bagi sekolah-sekolah swasta berbasis keagamaan. Paper presented in the seminar of education, Sanata Dharma University in cooperation with Asosiasi Sekolah-sekolah Jesuit Indonesia, August 16, 2014.

Budiraharjo, M., Muljani, R., Baskara, R, Nurmandi, A., Mutiarin, D., \& Qodir, Z. (2014, upcoming). The Role of Civil Society Organization in Education Service (Case Study Catholic Foundation and Muhammadiyah Organization, Indonesia), makalah untuk dipresentasikan dalam ICONPO, Malaysia, 25-27 Agustus 2014.

Carey, L. \& Dick, W. (1996). The systematic design of instruction. New York: Longman.

Darling-Hammond, L. (1997). The right to learn: A blueprint for creating schools that work. San Francisco: Jossey-Bass.

Dawson, J. (2005). A history of vocation: Tracing a keyword of work, meaning, and moral purpose. Adult Education Quarterly, 55(3), 220-231.

Hansen, D.T. (2008). Values and purpose in teacher education. In M. CochranSmith, S. Feinman-Nemser, D.J. McIntyre, \& K. Demers (Eds.), Handbook of research on teacher education (3rd ed., pp.10-26). New York: Association of Teacher Education.

Kliebard, H.M. (2004). The struggle for the American curriculum 1893-1958 (3rd Ed.). New York: Routledge Falmer.

Mezirow, J.J. (1978). Perspective transformation. Adult Education, 28(20), 100-110.

Mezirow, J., \& Associates (2000). Learning as transformation: Critical perspectives on a theory in progress. San Francisco: Jossey-Bass.

Moran, D. (2000). Introduction to phenomenology. New York: Taylor \& Francis.

Moustakas, C. (1994). Phenomenological research methods. Thousand Oaks, CA: Sage.

Ozar, L. (1994). Creating a curriculum that works: A guide to outcome-centered curriculum decision making. NCEA.

Palmer, P.J. (1998). The courage to teach. San Francisco: Jossey-Bass.

Pinar, W.F., Reynolds, W.M., Slattery, P., \& Taubman, P.M. (1995). Understanding curriculum: An introduction to the study of historical and contemporary curriculum discourses. New York: Peter Lang.

Sokolowski, R. (2000). Introduction to phenomenology. Cambridge, UK: Cambridge University Press.

Sprinthall, N.A., Reiman, A.J., Thies-Sprinthall, L. (1996). Teacher professional development. In J. Sikula, T.H. Buttery, \&. E. Guyton (Eds.). Handbook of research on teacher education (pp. 
666-703). New York: Simon \& Schuster Macmillan.

Tyler, R.W. (1949). Basic principles of curriculum and instruction. Chicago: The University of Chicago Press.

Van Manen, M. (1990). Researching lived experience: Human science for an action sensitive pedagogy. New York: State University of New York Press.

Wiggins, G. \& McTighe, J. (2005). Understanding by design (Expanded 2nd Ed.). Alexandria, VA: Association for Supervision and Curriculum Development. 
